Meta

Journal des traducteurs

Translators' Journal

\title{
Literary Translation Theory in Brazil
}

John Milton

Volume 41, numéro 2, juin 1996

Traduction et terminologie au Brésil

Translation and Terminology in Brazil

URI : https://id.erudit.org/iderudit/003652ar

DOI : https://doi.org/10.7202/003652ar

Aller au sommaire du numéro

Éditeur(s)

Les Presses de l'Université de Montréal

ISSN

0026-0452 (imprimé)

1492-1421 (numérique)

Découvrir la revue

\section{Citer cet article}

Milton, J. (1996). Literary Translation Theory in Brazil. Meta, 41(2), 196-207. https://doi.org/10.7202/003652ar

\section{Résumé de l'article}

Cet article se penche sur la théorie de la traduction littéraire au Brésil. On présente d'abord l'œuvre des frères Haroldo et Augusto de Campos qui furent à l'origine de la première école de traduction littéraire au Brésil, pour ensuite examiner des approches subséquentes. d'utilisation que vous pouvez consulter en ligne.

https://apropos.erudit.org/fr/usagers/politique-dutilisation/ 


\title{
LITERARY TRANSLATION THEORY IN BRAZIL
}

JOHN MILTON

Universidade de São Paulo, São Paulo, Brazil

a sempre desprezada, embora nem sempre desprezível, tradução dominical (Jorge Wanderley)

\section{Résumé}

Cet article se penche sur la théorie de la traduction littéraire au Brésil. On présente d'abord l'auvre des frères Haroldo et Augusto de Campos qui furent à l'origine de la première école de traduction littéraire au Brésil, pour ensuite examiner des approches subséquentes.

\begin{abstract}
This article will examine literary translation theory in Brazil. It will first look at the approach used by brothers Haroldo and Augusto de Campos, which could be considered as veritable translation school of thought. It will then examine other approaches.
\end{abstract}

\section{THE CAMPOS BROTHERS}

The ideas of Augusto and Haroldo de Campos on translation are quite transparent. I shall enumerate them with the help of Jorge Wanderley's studies ${ }^{1}$ and Ana Cristina Cesar's essay "Nos Bastidores da Tradução"2 (In the Wings of Translation).

i) Their entire work - their translations and their articles on translation - has a definite shape and coherence. They have translated only the authors they believe have affected, changed or revolutionised poetic form: firstly Pound, cummings, Joyce and Mallarmé; and then Maiakovski, Khlebnikov, Valéry, Poe, the Provençal troubadours, Goethe, Octavio Paz, Lewis Carroll, Keats, Edward Lear, John Donne and John Cage. They often quote Maiakovski pointing out the importance of new forms: "Sem forma revolucionária não há arte revolucionária" (With no revolutionary form there is no revolutionary art). ${ }^{3}$ In "Nos Bastidores da Tradução", Ana Cristina Cesar calls their attitude toward translation "um sentido ativo de missão" (an active sense of mission).${ }^{4}$ Haroldo de Campos uses equally strong terms:

...só me proponho traduzir aquilo que para mim releva em termos de um projeto (que não é apenas meu) de militância cultural. 5

The qualities the Campos brothers admire can be seen in Augusto de Campos' introduction to his translations of cummings:

... do lado de Pound e Joyce ... Cummings (sic) é dos poucos que mantêm uma sadia atitude de inconformismo, pesquisando os meios de levar à consequências profundas, num plano de funcionalidade, os assumos de rebeldia intentadas pelos grupos das décadas iniciais ... permanecem esses três, com uma obra viva e aberta, a apontar sendas de superação aos mais jovens $\mathrm{e}$ a fornecer "nutrimento de impulso a novas expansões. 6

Ana Cristina Cesar emphasises the political element in their work. They have: 
uma atitude bastante política, uma vez que se expressa dentro de uma estrutura coerente de valores pró/contra e de conceitos de poesia nos termos "dominador/dominado".?

ii) The importance of poetry is not so much in the content as in the form. The translator must favour translating the form of the poem he is working on, even if this means sacrificing the content. The Campos Brothers consciously attempt to introduce new syntactical, lexical and morphological forms into Portuguese. Haroldo de Campos states:

$O$ tradutor alarga as fronteiras de sua própria língua e subverte-lhe os dogmas ao influxo do texto estrangeiro. 8

In Verso, Reverso, Controverso, Augusto de Campos uses similar language:

...parece importante alargar o horizonte de nossa linguagem poética, reproduzindo em português alguns dos poemas de Laforgue e Corbière. ${ }^{9}$

Their attempt to introduce new morphological forms can be clearly seen in their translation of excerpts from Finnegan's Wake:

Ela era só uma tímida tênue fina meiga mini mima miga duma coisinha então, saltiritando, por silvalunágua e êle era um bruto andarulho larábil ferramundo dum Curraghman, cortando o seu feno para o sol cair a pino, tão rijo como os carvalhos (deus os preteje!) costumavam ruflar pelos canais do fortífero Kildare, o que primeiro florestfossenfiou champinhando através dela. Ela pensou que ia sussimir subterra de ninfante virginha quando êle lhe botou o ôlho de tigris! (Translated by Augusto de Campos) ${ }^{10}$

iii) The main influences behind their theory of translation are Walter Benjamin, Roman Jakobson and Ezra Pound. From Benjamin they take the idea of the source language influencing the target language, as we saw in the previous section (ii, above). From Jakobson they take the idea of translating the form of the source language into the target language. And from Pound they take the idea of the translator as recreator. ${ }^{11}$ The terms and neologisms they use for their translations are Pound's grandchildren:

recriação, transcriação, reimaginação (caso da poesia clássica chinesa), transparadisação ou transluminação (Seis Cantos do Paradiso de Dante) e transluciferaçáo mefistofáustica (Cenas Finais do Segundo Fausto de Goethe). ${ }^{12}$

Among the neglected Brazilian authors they have championed is the poet and translator from Maranhão, Odorico Mendes (1799-1864). Mendes translated the Aeneid and lliad into a Portuguese which tried to find equivalents for many of the Latin and Greek lexical items. Where a word didn't exist in Portuguese, he created a neologism. Some are less successful, e.g., "velocípede Aquiles" than others, e.g., "Irís alidourada," "crinazul Netuno." He also tried to situate the classical texts in Brazilian reality. His notes compare the jangada used by Ulysses with that of the jangadeiros of Ceará. Another technique he used was to interpolate lines from other poets (Camoens, Francisco Manuel de Melo, Antônio Ferreira, Filinto Elisio) when he thought this was the most suitable way of rendering the line. As we shall see, the Campos brothers borrow this technique.

However, Odorico Mendes' translations aroused the wrath of many Brazilian critics. For Silvio Romero, his translations were "monstruosidades" written in "português macarrônico". 13 Antônio Cândido shares this opinion:

alastrando a sua tradução da llíada de vocábulos e expressões que tocam as raias do bestialógico e que Silvio Romero já fez a devida justiça: multimamente, olhicetílea, albinitente. ... um preciosismo do pior gosto, enfático, vazio em que o termo raro, a imagem descabida, a construção arrevezada até a obscuridade são apoios duma inspiração pobre, em fase de decadência. ${ }^{14}$ 
By contrast, Haroldo de Campos places Odorico Mendes very much in the tradition of craftsmen of the language, the tradition of Joyce, with his "palavras-montagem," or Guimarães Rosa, with his "inesgotáveis invenções vocabulares."15

iv) The translator must be fully integrated with contemporary currents in poetry.

... se o poeta-tradutor não estiver ao nível curricular da melhor e mais avançada poesia do seu tempo, não poderá reconfigurar, síncrono-diacronicamente, a melhor poesia do passado. ${ }^{16}$

Ana Cristina Cesar makes further comments:

v) "Irreverência temática." 17 As well as favouring poets who introduced new forms, the Campos brothers choose to translate poets who write about unorthodox topics. Examples are Donne's The Flea and other metaphysical poems; Lewis Carroll's "nonsense" poems and the cummings' poems which emphasise visual format.

vi) "Tecnologia poética ou artesanato formal rigoroso."18 Rather than working with poets who emphasise emotional states or existential problems, the Campos brothers work with poets who deliberately use language as an instrument and experiment with the various elements of language. A good example is the Provençal poet, Arnaut Daniel, who experiments with a number of different types of end rhyme. Indeed, all Provençal poetry suits the purposes of Augusto de Campos:

mas o que há de novo na poesia de Provença, a justificar a sua presença em plena era tecnológica? Há, em primeiro lugar, precisamente, a tecnologia poética, o trabalho de estruturação e de ajuste das peças do poema, em termos de artesanato. ${ }^{19}$

The poems the Campos brothers translate often echo the ideogrammatic form of much concrete poetry. Examples are George Herbert's The Altar and Easter Wings and Lewis Carroll's Tail-Poem, where the poems themselves are in the shape of an altar, a pair of wings and a tail. Needless to say, the translations of Augusto de Campos, the first two in Verso, Reverso, Controverso ${ }^{20}$ and the third in $O$ Anticritico ${ }^{21}$, form identical shapes.

vii) For Ana Cristina Cesar, the Campos brothers favour poems where there is some intentional difficulty or obscurity. They consider Mallarmé's adage, "ajouter un peu d'obscurite," 22 positive, as it ensures that the reader must approach the poem with greater objectivity, in contrast to the ease with which a more subjective emotional poem may be understood. They prefer cerebral, rational poets. Thus we can understand their enthusiasm for the Metaphysical poets and their disregard for the Romantics. In summarising the qualities Dryden and Johnson disliked in the Metaphysicals, Augusto de Campos puts forward the kind of poetry he himself favours:

O que se condena. com esse ritual eufemístico, nos poetas "metafísicos" é, na verdade, a intervenção do pensamento, do raciocínio, ou mais ainda, da racionalidade, onde parecera lícito usar apenas da emoção e do sentimento: condena-se em resumo, uma poesia dirigida mais ao cérebro que ao coração. ${ }^{23}$

Other points are made by Jorge Wanderley: viii) The Campos brothers make a definite imposition on the reader. The tone is that of "take us or leave us," or, in the words of Jorge Wanderley, "Après moi le déluge" 24 and more bluntly, "que tudo o mais vá pro inferno." 25 Their work contains an "autoritarismo da RUPTURA." 26 The translator/poet must break with tradition. If he doesn't, he is hardly worth considering. There is even a certain snobbery towards other "ordinary" translations. This can be seen in Haroldo de Campos' comments on "inferior" translations of The Raven in Deus e o Diabo no Fausto de Goethe: 
Vejamos agora como se comportam diante do mesmo texto-amostra as traduções comuns, naturais, destituídas de um projeto estético radical. 27 taries:

ix) This excessive self-confidence can often be seen in their prefaces and commen-

Mallarmé: tradução em triálogo, tridução (Décio dixit), palavras da tribo, tributo. E depois de Pound (Cantares), cummings (10 poemas, um solo, Augusto performing), Joyce (Panaroma, a duas vozes, i fratelli de Campos, turgimanos siamesmos), novamente o trio em tríptico, um Mallarmé que vem sendo trigerado desde os anos 50 completa agora o quadrante da circunviagem: paiduma, quadrívio. 28

Jorge Wanderley describes this as a "jubilosa auto-contemplação," 29 which shows that the coming together of the Campos brothers and Mallarmé is an "espécie de conjunção astral afortunada, cometa que não se dá a qualquer século."30

Yet their eloquence often covers up certain weaknesses in their arguments. Jorge Wanderley mentions Haroldo de Campos' essay, "O Tex to-Espelho (Poe, Engenheiro de Avessos)," in which he dissects the effects Poe achieves through his repetition of certain sounds. Haroldo de Campos analyses his own translation of the second line of the final stanza of The Raven:

On the pallid bust of Pallas just above my chamber door.

No pálido busto de Palas, justo sobre meus umbrais. 31

He emphasises that the phonemes / $\mathrm{u} /$ and /b/ "estão ainda em UMBRAIS." 32 However, as this vowel is nasalized, it is not the same as that of busto and justo.

In addition, the connection between RAVEN and NEVER which Haroldo de Campos makes at great length seems somewhat forced to Wanderley. In Poe's poem they appear near each other on only one occasion. The word NEVER appears only once; it is NEVERMORE that appears frequently and from which Haroldo de Campos extracts his NEVERs.

$\mathrm{x})$ Perhaps the most interesting point that Jorge Wanderley makes is that despite their radical rhetoric, the work on translation of the Campos brothers is "capaz de não ser radical." 33 He fails to find a Poundian "Make It New" policy running throughout their work. What he finds instead is the use of different translation techniques within the same poem. In Augusto de Campos' translation of Marvell's To His Coy Mistress there are lines of seven, eight and ten syllables to translate Marvell's octosyllables. Sometimes Augusto de Campos follows Marvell's rhyming couplets, and sometimes he doesn't, and he adds three lines to Marvell's 46 lines. It seems that the translator is primarily trying to translate the movement of Marvell's language and is subordinating the metre and rhyme scheme to this. In other words, Augusto de Campos, rather than choosing to strictly obey either metre or rhyme scheme, or ignoring both, is "valendo-se de recursos normativos plurais," 34 an original, but hardly a radical Poundian technique. Indeed, many of the Campos' brothers' translations, e.g., those of Pound's Cantos, Mallarmé's Coup de Dés and the French poet's other poems, and those of Donne, do follow the original rather closely.

xi) To complete my analysis of the Campos brothers, I must emphasise the role they have played in bringing the work of the foreign poets they have translated to the attention of the Brazilian public. Their seriousness and coherent plan has made the translation of poetry, in the words of Jorge Wanderley,

algo muito diferente da sempre desprezada, embora nem sempre desprezível tradução dominical, operada sem cerimônias e sem a visão fundamental: a de que na traduçäo tudo está... Com esta mudança de eixo, o grupo instaura, ademais no panorama brasileiro uma 
visão... de que a tradução passe a ser considerada como chave para o literário e suas relaçóes com o que nos cerca. ${ }^{35}$

\section{JOSÉ PAULO PAES}

A very different line is taken by the the critic, poet and translator of Kavafis, Tristam Shandy, W. H. Auden, William Carlos Williams, Paul Éluard, Hölderlin, amongst others, José Paulo Paes. He takes a position opposite that of the Campos brothers in relation to their enthusiasm for the translation which follows the form of the original. He ironises the kind of neologism which introduces elements of the morphology of the original into the target language, mentioning the "semi-decalque... em voga no mundo secretarial das multinacionais ... (que)... se demonstra uma inutilidade, uma superafetação numa língua que já dispõe de correspondentes." 36 As an example he gives the translation made by Luís Gonçalves Bueno de Camargo of a compound adjective used by Gerald Manley Hopkins: "Dapple-dawn-drawn." It is translated as "marcha-manhã-marcado." José Paulo Paes accepts the original, "não destoa da índole da língua inglesa," but he rejects the translation into Portuguese, "soa como extravagância...violação...um caso de sobretradução." 37 He takes advantage of the expression of George Steiner "cenatur language" 38 to describe this type of "inter-language" or "half-language." He also refers to Steiner's reference to Hölderlin's translations from the Greek as being "the most violent, deliberately extreme act of hermeneutic penetration and appropriation of which we have knowledge." 39 However, Paes gives the false idea that Steiner despises Hölderlin. This is not the case as Steiner shows considerable admiration for Hölderlin's translations. ${ }^{40}$

The way in which Steiner sees translation has a lot in common with Steiner's ideas on appropriation. 41 The ideolect of the poet originates in the naming of Adam in the Garden of Eden, but this ideolect reinforces the sociolect of society due to the fact that the poet normally writes for society. The translator departs from the sociolect of one language and arrives at the sociolect of another language:

ó que, por força da refração lingüistica - o tránsito por meios de diferente densidade - , renconstrói não o mesmo idioleto, mas outro, equivalente dele e congenial da língua meta. ${ }^{42}$

The translator attempts to put together again the ideolectal poem in the target language. This movement reverses the original movement of writing the poem - ideolect $\rightarrow$ sociolect - sociolect $\rightarrow$ ideolect. For José Paulo Paes "a confusão de Babel se resolve outra vez na ordem edênica da nomeação."43

\section{OTHER GROUPS OF BRAZILIAN TRANSLATORS}

In his M.A. thesis, A tradução do poema. Notas sobre a experiência da geração de 45 e dos Concretos, 44 Jorge Wanderley compares the concrete translators with the socalled "Geração de 45" translators, Pêricles Eugênio de Silva Ramos, Geir Campos, Jamil Almansur Haddad and Lêdo Ivo, whose work began in the forties and fifties and who are still writing today. We find the poetics of the translations of this group very similar to the poetics of their poetry: they emphasise the value of formal perfection and rigour of composition; they show a concern for beauty and adornment which leads them to be called "neoparnassians;" indeed, their poetry is a reaction against many of the values of Brazilian modernist poetry.

It is much more difficult to schematize the beliefs about translation of the Geração de 45 as they never reason on why they adopt certain attitudes in their translations. Moreover, we even find members of the group attacking each other. A large part of Geir 
Campos' Tradução e Ruído na Comunicação Teatral ${ }^{45}$ is devoted to attacking Pêricles Eugênio de Silva Ramos' translation of Hamlet.

One characteristic is that they have an unquestioning acceptance that the "great" works of European poets, particularly French poets, must be translated into Portuguese. The translator must keep as close as possible to the original; according to Jamil Almansur Haddad, he must be faithful to the "sonho nirvânico de aniquilarse diante da obra que traduz." 46

The only point in which the Geração de 45 have something in common with the Concrete translators is in the way the act of translation is sometimes described. We find a similar epiphanistic celebration in Lêdo Ivo describing his moment of vision as we found in the Campos brothers' joyous self-contemplation:

Quando acabei de traduzir Rimbaud, caia sobre a paisagem que eu fitava uma inaudita chuva de granizo. Tudo ficou sereno, de repente, e o arco-íris, que, criança, contemplei na paisagem total, atrevessou o céu de lado a lado e tinha as cores das vogais do soneto de Rimbaud. ${ }^{47}$

Jorge Wanderley's doctoral dissertation, A tradução do poema entre poetas do modernismo: Manuel Bandeira, Guilherme de Almeida, Abgar Renault, ${ }^{48}$ analyses the translations of these three modernist poets. However, he fails to find points in common. Bandeira's translations, very much an extension of his own poetry, are noticeable for their frequent distancing from the source text, ignoring a word for word translation to give a general impression of the original. Indeed, a number of his translations, such as the updating of the Castro Alves sonnet, Adeus de Teresa, and those of Elizabeth Barrett Browning's sonnets, are generally recognised to be better than the originals. What Wanderley particularly notices about Bandeira's attitude to translation is its very casualness and modesty. He even admits, "sou bastante fundo no inglês." 49 He prefers to work "seguindo o próprio nariz do que acompanhando paidumas" and in his Poemas Traduzidas 50 translates the recognised "greats" such as Goethe, Hölderlin, Paul Éluard and Ruben Dario, together with virtually unknown Latin American poets he happened to know personally. 45 group:

To Jorge Wanderley, Guilherme de Almeida seems to belong to the Geração de

aparece como um poeta de 22 que tivesse vivido à espera do espírito de 45 para aí se declarar plenamente em casa. 51

His translations, rigid, rigorous and conservative, share all the characteristics of the Geração de 45 . His notes, which anatomically dissect his translations, state his worry about producing versions of Baudelaire and the other French poets he specialises in translating which are as close as possible to the originals. According to Jorge Wanderley:

É uma preocupação que mostra o tradutor a trabalhar como se estivesse diante de um olhar vigilante e punitivo, grande fantasma de culpa dos eruditos... O purismo ultra-acadêmico... se volta para dar satisfações a um exigente monstro literário e gramático... (que) só existe mesmo... na cabeça de quem o concebe. 52

Abgar Renault, a relatively unknown poet and translator, translated the English war poets into Portuguese. His success is mixed. He captures a certain climate, "elegíaco, nobre, digno, contido mas sempre vigoroso," 53 but his work also contains "ingenuidades quase-amadorísticas como o recurso não só pragmático a rimas no infinito, inversões a arcaísmos." 54 Despite not having any theoretical design, Abgar Renault 's translations mainly attempt to adapt the English syntax of the poems he is translating to Portuguese. 
Although Jorge Wanderley fails to find any general characteristics of modernist translators, (and I believe a wider study of modernist translators is necessary here), he does connect Manuel Bandeira and Guilherme de Almeida with the succeeding generations of translators:

o autorismo óbvio da teoria da tradução existe em estado latente na dos concretistas, que recomenda enfaticamente o liberalismo, obriga a ser livre, sob pena de ser banal em desobedecendo. Por isto, ao fim de contas, o náo-me-importantismo de Manuel Bandeira, o leve ar de molecagem que há por trás de suas transgressöes, sua ausência de sisudez (compara-se o "sou bastante fundo no inglês" com Haroldo de Campos defendendo a validade ... dos seus conhecimentos de chinês - tudo isto termina por fazer de Manuel Bandeira, na realidade, a mente menos rígida, por trás das três teorias. 55

\section{OTHER WORK ON LITERARY TRANSLATION IN BRAZIL}

Other work on literary translation in Brazil is not as clearly defined, and it is not possible to distinguish any other schools of literary translation. There are certain patterns which articles on literary translation tend to follow. The first is that of "Dos and Don'ts." The writer will advise the prospective translator not to fall into certain traps and how to avoid certain certain false cognates. Examples of this are "Beware of les Faux Amis" 56 by Agenor Soares dos Santos, "Questões de Tradução"57 by Zélia de Almeida Cardoso and Paulo Rónai's books, Guia Prático de Tradução Francesa ${ }^{58}$ and Escola de Tradutores. ${ }^{59}$

A second type is that of personal reminescences. A translator will explain his or her problems when translating a certain work. A large amount of material falls into this category. The titles often reveal the content: Paulo Rónai's A Tradução Vivida; 60 A Tradução da Grande Obra Literária (Depoimentos);61 "Uma Odisséia Traductora"62 by José Paulo Paes.

A third standard kind of article compares different translations of the same poem. These are often highly prescriptive. In "Emily Dickinson Brasileira"63 Walter Carlos Costa compares translations of Emily Dickinson by Manuel Bandeira, "tem valor poético... só não contém poesia dicksoniana (sic;)"64 Mário Faustino, "permite... para quem não domina o inglês, conferir no original as qualidades de Emily;" 65 Aila de Oliveira Gomes, "Apesar da falta de ousadia das soluções, ... contém versos felizes;" 66 Idelma Ribeiro de Faria, "A mais apressada e antipoética;"67 and Augusto de Campos, "[Emily Dickinson] encontra, finalmente, no Brasil, uma dicção paralela à sua." 68 In a similar manner, Erwin Theodor sets himself up as a judge. In "A tradução de Obras Alemãs no Brasil" 69 he compares the versions of Hölderlin's Hälfte des Lebens of Manuel Bandeira and Paulo Quintela and then produces his own rendering.

As far as theory of literary translation is concerned, there is a somewhat confusing picture. A number of articles juxtapose quotations and references from various disparate critics. In the first two pages of "Literalidade e Criatividade na Tradução"70 Geir Campos randomly quotes from translator of Classical literature, William Arrowsmith, writers on linguistic theories of translation, Peter Newmark and Eugene A. Nida, the German Romantic, August Wilhelm Schlegel, the Canadian discourse analyst, Jean Delisle, Octavio Paz, Paulo Rónai, to mention only a few, in a heady cocktail of opinions from very different schools of translation theory. Never is there any attempt to place the different writers in their particular schools of thought and tradition.

So most writing on translation in Brazil has been much more concerned with the practical business of translating rather than more abstract theorising. Paulo Rónai admits his own lack of interest in translation theory: 
Por inclinação natural do meu espírito, a especulação abstrata pouco me atrai ... em vez de indagar a filosofia e a metafísicaa da tradução, preferi ater-me a seus problemas concretos. ${ }^{71}$

The same author is quite disparaging about Pound:

Não serei provavelmente capaz de saborear a versão de Pound tão integralmente como um leitor de língua inglesa; mas, ainda que por ela perpasse a vibração que lhe atribuem, custa-me considerá-la um padrão de tradução. ${ }^{72}$

Although there have never been any open battles on the field of translation in Brazil between, for example, pro- and anti-Poundians, a few skirmishes can be noted. One such flexing of the muscles took place in the Folha de Sào Paulo in 1985. Rosemary Arrojo reports this confrontation in her article "Paulo Vizioli e Nelson Ascher Discutem John Donne: A que são fiéis Tradutores e Críticos de Tradução ?"73 Ascher accuses Vizioli of translating Donne into outmoded language and praises Augusto de Campos' translation as "o trabalho magistral de um poeta." In his reply Vizioli wonders why Ascher thought Augusto de Campos' use of a line from Lupercínio Rodrigues "um lance realmente inventivo." Rosemary Arrojo steps into the ring to break the grapplers with her view that it is impossible to adjudicate which of the two translations is the better. Each translator of Donne has his own opinion of the poet's qualities and it is this view that will come over in the translation. Arrojo develops this concept of translation in her book Oficina de tradução ${ }^{74}$ Translation is a palimpsest: each new translation will erase previous versions and produce its own interpretation of the original. It is impossible to judge which is the best or whether there is a best translation.

Mário Laranjeira's Ph.D. dissertation, Do Sentido à Significância: em Busca de uma Poética da tradução, ${ }^{75}$ defends the point that a translation must take account of the significância of a poem. It must follow the original "não pela reprodução servil de uma estrutura-fora, mas por um trabalho na cadeia dos significantes capaz de gerar um poema autônomo e vivo."76 This concept of significânciais taken from Julia Kristeva:

a semánalise desvencilha-se da obrigatoriedade de um ponto de vista central único, o de uma estrutura a ser descrita - e oferece a si mesma a possibilidade de captações combinatórias que the restitui a estruturação a ser gerada. ${ }^{77}$

A good translation should reflect the relationship between the different elements of the poem. It is not just a matter of balancing form and content; it is rather "a resultante de um trabalho operado nos níveis semântico, lingüístico, estrutural e retórico-formal, integrados todos no nível semiótico-textual onde se dá a significância." 78

Mário Laranjeira goes on to analyse translations which managed to translate the significância and those which failed. The reader of Guilherme de Almeida's translation of Villon's Ballade des dames du temps jadis into archaic Portuguese "recebe o mesmo impacto do leitor francês." 79 Lêdo Ivo's translation of Rimbaud's Faim, on the other hand, "deixou-se perder-se a nível dos elementos essenciais para a passagem da mímese para a significância." 80 A tradução de Augusto de Campos (of cummings' $I$ was, $I$ am) respeita rigorosamente a manifestação textual do original no seu específico processo de significação."81 A successful translation will be able to take its place as a "text," not just as a translation, in the target language.

One of the most interesting recent works is Por uma Teoria Pós-moderna da Traduçâo, 82 by Else Ribeiro Pires Vieira. This doctoral dissertation attempts to find a suitable theory of translation to accomodate the Brazilian "post-modern" translations of the Campos brothers and Silviano Santiago. Else Vieira brings together Pierce's theory of the reversibility of the sign, allowing translation to be considered as a two-way movement along time and space, transcending traditional binary oppositions such as source/target, 
model/copy and superior/inferior. This is coupled with André Lefevere's ideas of translation as refraction: in every society translations will enter in a differrent way according to a large number of social, political and historical factors.

Very little has been written in terms of a historical or descriptive approach to literary translation in Brazil. José Paulo Paes has compiled a compact history of translation in Brazil in the Folhetim. ${ }^{83}$ Christl Brink has catalogued works translated from German to Portuguese in the post - Second World War period. ${ }^{84}$ Carlos Daghlian has listed all the translations made of Emily Dickinson's poetry in Brazil. 85 Nelly Novaes Coelho has examined the introduction of children's literature in Brazil in the nineteenth century. ${ }^{86}$ Most children's books in this period were either brought to Brazil in the French version (often translated from the English or German original) or from Portugal in a Portuguese translation of the French version. In addition, Nelly Novaes Coelho looks at the different genres of imported children's literature, right from the early translations and adaptations of Walter Scott and Robinson Crusoe to contemporary comic strips.

Sergio Bellei compares Fermando Pessoa's very accurate translation of Poes The Raven, in which he succeeds in recreating many of Poe's poetic techniques, with that of Machado de Assis, which ignores the rhyme schemes and the internal rhymes of the original and minimizes "the significance of the individual drama of the lover and ... replace(s) it by emphasising the raven as symbolic of loss, doubt and undying, painful remembrance of love forever lost." 87 Bellei gives his reasons for this change of direction:

Unlike Pessoa, Machado is the writer in the colony who was suffering from a peculiar kind of anxiety of influence and who was particularly aware of the implications of this anxiety for the construction of nationality in literature. ${ }^{88}$

Rather than "translating" Poe, Machado is "appropriating" him to echo the themes of the Occidentais, the volume which this translation opens. Bellei introduces the concept of "origins" versus "beginnings." Following the work of Mario Curvello, he states that Machado was always aware of the debt that Brazilians owed to their European origins and was therefore suspicious of attempts to make "new beginnings." A balance between the two elements could be made by the "appropriation" of foreign texts. Thus the Brazilian writer could produce a work which would contain both "origins" and "beginnings," as is done in Machado's translation of The Raven.

Onédia Barbosa's Byron in Brasil: Traduções ${ }^{89}$ analyses all the translations done of Byron's work in Brazil between 1832 and 1914. Byron's influence in Brazil in the second half of the nineteenth century was enormous and he even became a cult figure, both in fashionable circles and amongst students, among them students from the Faculdade de Direito, São Paulo, who held supposedly macabre Byronesque ceremonies in the Cemitério da Consolação. Onédia Barbosa shows that until 1855 most translations of Byron were made directly from English, but after 1855 the majority were made from the French translations of Laroche, Barré and Pichot. Most of the translations were made by second-line poets into blank verse. And of the poems translated, Parisina, Childe Harold and Hebrew Melodies were the most popular. Indeed, such was the vogue for Byron in the nineteenth century that José de Alencar presents the hero of his novel Senhora Seixas, a fashionable Carioca dandy, as a translator of Byron:

Às vezes repetia as traduções que havia feito das poesias soltas do bardo inglês; essas jóias literárias, vestidas com esmero, tomavam maior realce na doce língua fluminense, e nos lábios de Seixas que as recitava como trouvador. 90

Gentil de Faria continues Onédia Barbosa's work of examining translations from English in Brazil studies of the influence of Oscar Wilde in Brazil. His M.A. thesis con- 
tains a comprehensive list of all the translations of Wilde done in Brazil. ${ }^{91}$ As in the case of Byron, the literary image of Wilde in Brazil was very different from that in Britain. Wilde's social comedies remained relatively unknown; The Importance of Being Earnest was only translated for the first time in 1960. The Wilde Brazil imported was the French version, the aesthete par excellence. In A Presença de Oscar Wilde na "Belle Époque" Literária Brasileira, ${ }^{92}$ Gentil de Faria demonstrates that the great majority of translations of Wilde were done from the French and his most popular works in Brazil, The Ballad of Reading Gaol, Salomé and The Portrait of Dorian Gray were very influential amongst Brazilian decadentismo writers in the first twenty years of the century. Indeed, the Modernists reacted against Wilde and his influence. Gentil de Faria quotes Menotti del Picchia, who says Wilde is one of a number of authors who should be "killed" as his work is "postiço, artificial, arrevezado, precioso."93

A survey of the theory of literary translation in Brazil, then, presents us with a rather patchy picture, one, which I think, would be similar to that in most countries. The profile of the Campos brothers is sharp and crystal clear, and Mário Laranjeira puts forward his argument for translating the significancia of a poem, but the rest of the field is vague and nebulous. Jorge Wanderley presents us with an outline of the views on translation of the Geração de 45 but fails to find a "modernist" theory or approach to translation.

And how does literary translation in Brazil fit in with other theories of literary translation? The Campos brothers recognise Pound, Benjamin and Jakobson as their mentors. But most other discussions on translation seldom get away from traditional arguments of form versus content found in Cicero, Jerome and the Augustans. Dryden's parameters of metaphrase, paraphrase and imitation still guide most references to translation here in Brazil.

Notes

The quotation on the title page is from $A$ tradução do poema. Notas sobre a expêriencia da geração de 45 de dos Concretos, p. 158. For complete references see note 1.

1. A tradução do poema. Notas sobre a expêriencia da geração de 45 e dos Concretos, Jorge Wanderley. M.A. dissertation, PUC, Rio de Janeiro, 1983.

A tradução do Poema entre poetas do modernismo: Manuel Bandeira, Guilherme de Almeida, Abgar Renault, Jorge Wanderley. Ph.D. thesis, PUC, Rio de Janeiro, 1988.

2. "Nos Bastidores da tradução," Ana Cristina Cesar. In Escritos de Inglaterra, Brasiliense, São Paulo, 1988.

3. For example, in "O texto como produção," Haroldo de Campos, in A Operação do Texto, Perspectiva, São Paulo, 1976, p. 45.

4. "Nos Bastidores da Tradução," op. cit., p. 142.

5. In "Octavio Paz e a Poetica da Tradução," Haroldo de Campos, in Folhetim, Folha de São Paulo, 9 de janeiro de 1987

6. In "e.e. cummings: olho e fôlego," in e.e. cummings 40 POEM(A)S, Ministério de Educação e Cultura, Serviço de Documentação, Rio de Janeiro, 1960.

7. In "Nos Bastidores da Tradução," op. cit., p. 143.

8. In footnote to "O texto-espelho (Poe, engenheiro de avessos)," In A Operação do texto, op. cit., p. 35.

9. In Verso, Reverso, Controverso, Augusto de Campos, Perspectiva, São Paulo, 1979, p. 214.

10. Panaroma de Finnegan's Wake, Augusto e Haroldo de Campos, Perspectiva, São Paulo, 1970, p. 57.

11. For references to Benjamin see particularly "Transluciferação mefistofáustica," in Deus e o Diabo no Fausto de Goethe, Haroldo de Campos, Perspectiva, São Paulo, 1981. Jakobson's influence on Haroldo de Campos' thinking can be seen particularly in "O texto-espelho (Poe, engenheiro de avessos)." The Campos brothers constantly pay homage to Pound, see particularly Ezra Pound, Poesia, translations by Augusto and Haroldo de Campos, Décio Pignatari, J. L. Grünewald and Mário Faustino. Huctitec, São Paulo, 1985. This beautifully produced book celebrated the hundredth anniversary of Pound's birth. However, it seems to me that the Campos' brothers actual strategies of translating are little influenced by Pound's concept of "Make It New." This was the point of a paper I presented, "Do the Campos Brothers Really Make It New or Do They Just Pretend To?," at the XXII Seminário Nacional de Professores de Literatura Inglesa held in Poços de Caldas, MG, January, 1990. This paper developed some of the points Jorge Wanderley makes, which are presented in this chapter, see pages $262-263$

12. In "Octavio Paz e a Poética da Tradução," op. cit. 
13. In "Da Traduçao como Criação e como Crítica," in Metalinguagem, Haroldo de Campos, Cultrix, São Paulo, 1976, p. 27.

14. Quoted in Antônio Medina Rodrigues' Ph.D. Thesis: Odorico Mendes: Traduçäo da Épica de Virgílio e Homero, USP, 1980.

15. "Da Tradução como Criação e como Crítica," op. cit., p. 28.

16. From "Transluciferração mefistofáustica," op. cit., pp. 184-185.

17. "Nos Bastidores da Tradução," op. cit., p. 144.

18. Ibid., p. 144.

19. Verso, Reverso, Controverso, op. cit., p. 10.

20. Ibid., pp. 150-153.

21. O Anticrítico, Augusto de Campos, Companhia das Letras, São Paulo, 1986, pp. 130-131.

22. Quoted in Verso, Reverso, Controverso, p. 201.

23. Ibid., p. 214.

24. A tradução do poema. Notas sobre a expêriencia da geração de 45 e dos Concretos, op. cit., p. 126.

25. Ibid., p. 126.

26. Ibid., p. 8.

27. "Transluciferação mefistofáustica," op. cit., p. 184.

28. Mallarmé, "Nota Introdutória," Haroldo de Campos, In Mallarmé, Augusto de Campos, Haroldo de Campos e Décio Pignatari, Perspectiva, São Paulo, 1974.

29. A tradução do poema. Notas sobre a experiência da geração de 45 e dos Concretos, op. cit., pp. 135-136.

30. Ibid., pp. 135-136.

31. "O texto espelho (Poe, engenheiro de avessos)," op. cit., pp. 28-30.

32. Ibid., p. 39.

33. A tradução do poema. Notas sobre a experiência da geração de 45 e dos Concretos, op. cit., p. 157.

34. Ibid., p. 147 and p. 157.

35. Ibid., p. 158.

36. "Sobre a Tradução de Poesia," em Traduçāo: a Ponte Necessária, José Paulo Paes, Ed. Ática, São Paulo, 1990, p. 43

37. Ibid., pp. 44-45.

38. Ibid., p. 42

39. After Babel, George Steiner, Oxford, 1975, p. 323.

40. Ibid., pp. 323-333.

41. See ibid.

42. "Sobre a Tradução de Poesia," op. cit., p. 48.

43. Ibid., p. 48.

44. For full references see note 1 above.

45. Tradução e Ruído na Comunicação Teatral, Geir Campos, Álamo, São Paulo, 1982.

46. As Flores do Mal - Baudelaire, Jamil Almansur Haddad, Max Limonad, São Paulo, 1981, p. 11.

47. In $A$ tradução do poema. Notas sobre a experiência da geração de 45 e dos Concretos, op cit., p. 95.

48. A traduçẫo do Poema entre poetas do modernismo: Manuel Bandeira, Guilherme de Almeida, Abgar Renault, op. cit.

49. Ibid., p. 11. From Itinerário de Pasárgada.

50. Poemas Traduzidas, Manuel Bandeira, Ediçōes de Ouro, Rio de Janeiro, 1966.

51. A trudução do Poema entre poetas do modernismo..., op. cit., p. 142.

52. Ibid., p. 200.

53. Ibid., p. 208.

54. Ibid., p. 161.

55. Ibid., p. 143.

56. "Beware of Les Faux Amis," in Tradução e Comunicação, no 9, dez. 1986, pp. 59-64.

57. "Questões de Tradução," Zélia de Almeida Cardoso, in Tradução e Comunicação, n 4, julho 1984, pp. 119-128.

58. Guia Prática de Tradução Francesa, Paulo Rónai, Educom, Rio de Janeiro, 1975.

59. Escola de Tradutores, Paulo Rónai, Educom, Rio de Janeiro, 1976.

60. A Tradução Vivida, Paulo Rónai, Nova Fronteira, Rio de Janeiro, 1981.

61. A Traduçāo de Grande Obra Literária (Depoimentos), org., Waldiva Marchiori Portinho, Álamo, São Paulo, 1982

62. "Uma Odisséia Tradutoria," José Paulo Paes, In Tradução e Comunicação, no 6, julho 1985, pp. 35-48.

63. "Emily Dickinson brasileira," Walter Carlos Costa, in Ilha do Desterro, $\mathrm{n}^{\circ} 17,1$ st semestre 1987, Editora da Universidade Federal de Santa Catarina, Florianópolis.

64. Ibid., p. 79 .

65. Ibid., p. 81 
66. Ibid., p. 84.

67. Ibid., p. 86 .

68. Ibid., p. 86.

69. "A Tradução de Obras Literárias Alemãs no Brasil," Erwin Theodor, in Revista do Instituto de Estudos Brasileiros, $\mathrm{n}^{\circ} 16,1975$, pp. 57-58.

70. "Literalidade e Criatividade na Tradução," Geir Campos, in Tradução e Comunicação, no 7, dez. 1985 , pp. $9-20$.

71. Escola de Tradutores, op, cit., p. 176.

72. Ibid., p. 146.

73. "Paulo Vizioli e Nelson Ascher discutem John Donne: A que sào fiéis Tradutores e Críticos de Tradução?," Rosemary Arrojo, in Tradução e Comunicação, $\mathrm{n}^{\circ}$ 9, dez. 1986, pp. 133-142. Nelson Ascher's review of Paulo Vizioli's translation of John Donne's poems, John Donne: O Poeta do Amor e da Morte was published in the Folha de Sào Paulo, 29 de abril de 1985. On 5th May Paulo Vizioli's reply was published in the same newspaper, and on 12 th May Ascher's further reply was published.

74. Oficina de Tradução, Rosemary Arrojo, Ática, São Paulo, 1986.

75. Do Sentido à Significância: em busca de uma Poética da Tradução, Mário Laranjeira, Ph.D. Thesis, USP, 1989.

76. Ibid., p. 187

77. "Sémanalyse, et production de sens," Julia Kristeva, quoted by Mário Laranjeira, in ibid., p. 100.

78. Ibid., p. 160.

79. Ibid., p. 141

80. Ibid., p. 123

81. Ibid., p. 155

82. Por uma Teoria Pós-moderna da Tradução, Else Ribeiro Pires Vieira, Doctoral thesis, Universidade Federal de Belo Horizonte, 1992.

83. "A tradução no Brasil," José Paulo Paes, in Folhetim, Folha de São Paulo, 18 de setembro de 1983.

84. "Traduções de obras alemãs no Brasil," Kristl Brink, in Tradução e Comunicação, n' 5, dez. 1984, pp. 53-74.

"A literatura infanto-juvenil alemà traduzida no Brasil," Christl Brink, in Tradução e Comunicação, n"6, julho 1985 , pp. 49-72.

"Tradutores de obras alemãs no Brasil (1984-86)," Christl Brink, in Tradução e Comunicação, n 8 , julho 1986 , pp. 61-82.

85. In A Obsessão Irônica na Poesia de Emily Dickinson, Carlos Daghlian, Tese de Livre-Docência, UNESP, Sâo José do Rio Preto, 1987, pp. 26-291.

86. "Tradução: Núcleo geratriz da literatura infantil/juvenil," Nelly Novaes Coelho, in $1 /$ ha do Desterro, $\mathrm{n}^{\circ} 17$, op. cit., pp. 21-32.

87. "The Raven by Machado de Assis," Sergio Bellei, in Itha do Desterro, $n^{\circ}$ 17, op. cit., pp. 47-62.

88. Ibid., p. 61.

89. Byron no Brasil: Traduções, Onédia Célia de Carvalho Barbosa, Ática, São Paulo, 1975.

90. In Byron no Brasil: Traduçóes, op. cit., p. 259. See also A Escola Byroniana no Brasil, Pires de Almeida, Conselho Estadual de Cultura, São Paulo, 1962, for an idea of Byron's influence in Brazil.

91. Oscar Wilde no Brasil: Contribução aos Estudos da "Belle Époque" Literária Brasileira, Gentil de Faria, M.A. dissertation, Universidade de São Paulo, 1976.

92. A Presença de Oscar Wilde na "Belle Époque Literária Brasileira, Gentil de Faria, Pannartz, São Paulo, 1988.

93. Ibid., p. 215. 